\title{
AACSB - Does It Matter?
}

Donald Yates, (Email: dyates@uscupstate.edu), University of South Carolina Upstate Stuart Shough, (Email: sshough@uscupstate.edu), University of South Carolina Upstate

\begin{abstract}
Does the accreditation of a school of business by AACSB have any bearing upon the school's standing with the local population or is it primarily a term that is recognized only within academic circles and the townsfolk have no opinion? This paper outlines the results of a survey of the local population - both business people and non-business people - by a marketing research class at a local university. In order to not embarrass the respondents, they never posed the question "Do you know what it means to be AACSB certified?" However, they did ask other questions which enabled them to obtain sufficient information to answer the question, AACSBDoes It Matter?
\end{abstract}

\section{INTRODUCTION}

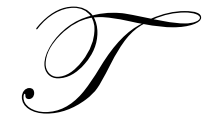

he faculty and the staff of the school of business in the local university had just spent many years struggling with completing the requirements needed to attain the coveted accreditation by AACSB. When the accreditation was finally earned and the school had gone through their first review, except for the fact that state's academic board of governors had decreed that all professional schools would be accredited by the profession's accrediting body, the faculty wanted to know if it was all worth it. However, trying to measure the value of the accreditation was both somewhat nebulous and elusive. However, some of the graduates did advise the faculty that it appeared to them that graduating from an AACSB accredited school made it easier to get accepted into graduate school. Very few students commented about how the accreditation affected their employment opportunities. The dean approached the instructor of the marketing research class and they discussed the possibility of the class doing a research project with the objective of determining how the local population viewed the university and the school of business when compared with other local colleges and universities.

\section{THE SURVEY}

The students were enthusiastic about the challenge and divided the class divided into teams in order to achieve multitasking problem solving. The tasks to be performed by the teams included, secondary research, questionnaire development, build the database, interview the sample population (everyone did interviews), code the responses and input the data into the database, analyze the results, prepare the written report and make the final presentation.

The composition of the questionnaire consumed much of the students' time initially as they felt that the questions had to be just right. They did not want to embarrass the respondent so they decided to not ask if they knew what

"AACSB" was or what it stood for. Instead, they asked questions designed to determine the factors local population would use to evaluate a university. On a scale of 1 to 5 , the results indicated that the business program at a college or university was the leading factor for evaluation (Chart 2) with a score of 4.3 out of a possible score of 5 . (Chart 1 is the question as presented in the survey).

The students conducted 266 interviews. The responses were edited, coded, and entered into the database. The results were then reviewed and analyzed. 


\section{THE RESULTS}

In Chart 3, we see that "Leadership Roles" and "Degree from Accredited School" tied for the second most important factor to consider when hiring a recent college graduate. This indicates that even though they may not know the meaning of AACSB, they do recognize the importance of hiring graduates from a school with a professionally accredited program. This is interesting because the students gathering secondary data visited the web site of some 35 schools which had been accredited by AACSB (Charts 4). Of this group, 17\% did not have any information about their accreditation; 55\% had limited information; $11 \%$ had additional information, while $17 \%$ (6 out of 35) had extensive information. These last schools "know where it's at" in that they recognize the importance of promoting themselves as a school with professional accreditation.

The next question asked the respondents to evaluate eight (8) local colleges and universities. (Chart 5). These schools are private, public, large and small the students were interested in the evaluation of their school (College \# 6) which scored a little above average. College \#6 is a public institution which, in the past, had been perceived as a branch of the state university, which was included in the list of eight. However, on the next question, the respondents were requested to evaluate the "quality of a business management education" as received from these eight schools. The actual raw data by value are given in Chart 6 . The average scores by school are given in Chart 7 .

The responses to this question indicated that the school of business management at College \#6 was perceived as having a program that was equal to or better than six of the other colleges, with only one school having a better score. school.

However, the questionnaire still did not help evaluate the population's perception of an AACS accredited

So, the last question was framed as follows:

AACSB is the highest professional accreditation that a collegiate business program can achieve. Only $25 \%$ of all business schools in the U.S. are AACSB accredited. College \#6 is AACSB accredited. Does this information improve your opinion of College \#6

yes _ no

Of the 74 respondents who had evaluated the quality of a business management education at School \#6 as "Average" or "Not Very Good" 72\% (53/74) responded "Yes". (Chart 8).

\section{CONCLUSION}

Yes, Dean Richard, AACSB Does Matter, so promote it!

\section{CHART 1:}

How important are the following factors when evaluating a university? (Please circle the number you feel describes the importance of each factor.)

\begin{tabular}{lccccc} 
& Excellent & Very Good & Average & Not Very Good & No Opinion \\
\hline Liberal Arts program & 5 & 4 & 3 & 2 & 1 \\
Engineering program & 5 & 4 & 3 & 2 & 1 \\
Business program & 5 & 4 & 3 & 2 & 1 \\
Teacher training & 5 & 4 & 3 & 2 & 1 \\
Medical program & 5 & 4 & 3 & 2 & 1 \\
Athletic program & 5 & 4 & 3 & 2 & 1 \\
Campus life & 5 & 4 & 3 & 2 & 1
\end{tabular}


CHART 2: How Important Are The Following Factors When Evaluating A University?



CHART 3:






\section{CHART 4: AACSB Secondary Information Summary}

- Out of the 35 schools visited, only 29 have information regarding the AACSB accreditation on their websites.

- Nineteen schools have limited information concerning AACSB accreditation on their website. The information presented includes the logo along with the definition of AACSB.

- Four schools have additional information on their websites that consist of the logo, definition, background, and importance of AACSB accreditation.

- Six of the 29 schools have extensive information such as, press releases, journals, full pages dedicated to explaining the relevance of accreditation to the school, and links to the AACSB official website

\section{CHART 5:}



CHART 6:

How do you perceive the quality of a business management education received from the following Upstate South Carolina colleges and universities?

\begin{tabular}{lccccc} 
& $\mathbf{5}$ & $\mathbf{4}$ & $\mathbf{3}$ & $\mathbf{2}$ & $\mathbf{1}$ \\
\hline College \#1 & 50 & 110 & 55 & 6 & 37 \\
College \#2 & 61 & 93 & 48 & 4 & 52 \\
College \#3 & 8 & 56 & 84 & 26 & 81 \\
College \#4 & 8 & 58 & 93 & 15 & 82 \\
College \#5 & 90 & 100 & 35 & 3 & 28 \\
College \#6 & 38 & 114 & 69 & 5 & 33 \\
College \#7 & 17 & 67 & 86 & 13 & 73 \\
College \#8 & 30 & 98 & 63 & 3 & 62
\end{tabular}


CHART 7:

\section{Perception of Quality of Business Management Education}

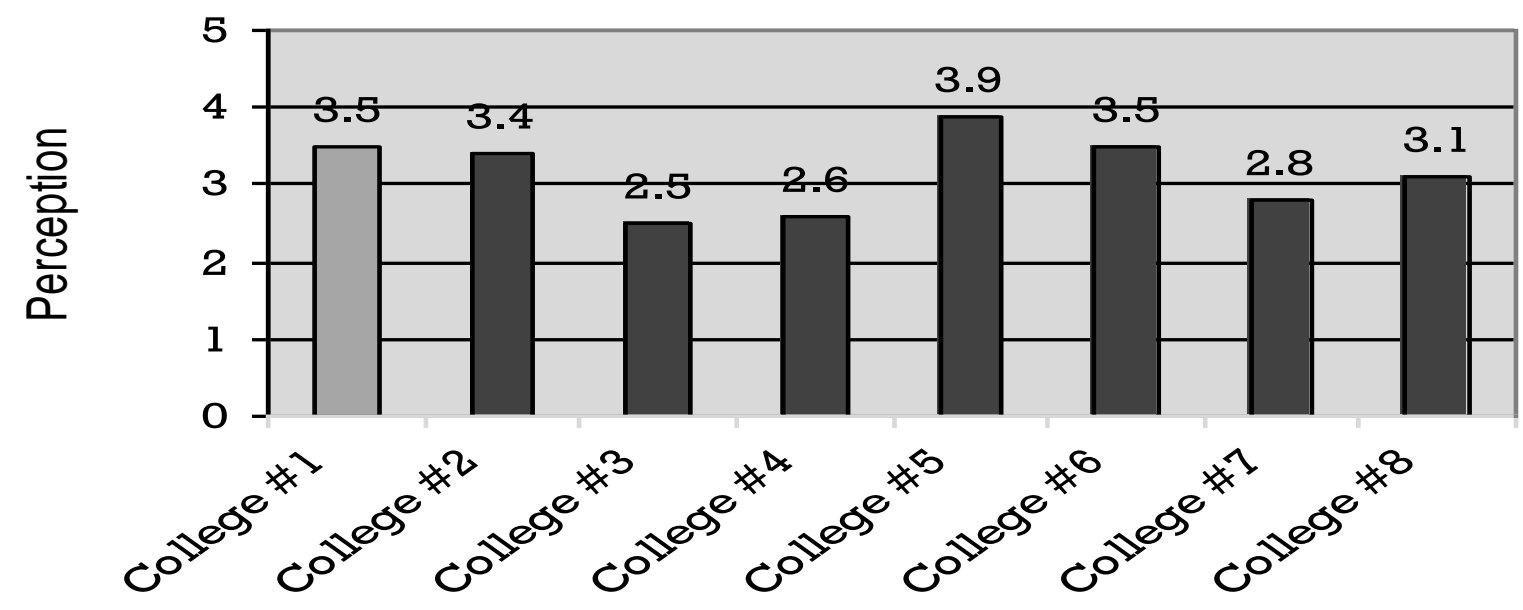

CHART 8: IMPORTANT CONCLUSION

Of The 74 Respondents Who Rated College \#6 Business Management Program As "Average" Or "Not Very Good" 72\% (53/74) Stated That Their Perception Of College \#6 Improved After Learning Thet The Business Management Program Was AACSB Accredited.

Therefore, AACSB Does Matter!!! 
NOTES 